with either cylinder wire, were surrounded by brass tubes sonnected with the earth. The sensitiveness of the electrometer was such as to produce for a $\Delta \mathrm{V}$ of $0.01 \mathrm{~V}$, a shifting of about $7 \mathrm{~mm}$. on the scale. The connection of the cylinder wires with the earth was brought about by touching them with brass wires connected with the earth. In the whole there was not on the path from the cylinder wire to the electrometer any contact of two different metals. The cylinder was charged, as a rule, to roo $\mathrm{V}$ by a battery of storage cells.

During the progress of these experiments a very interesting phenomenon presented itself. It was found that when either of the cylinders is connected with the earth, the wire enclosed within it, after being disconnected from the earth, immediately begins to get electrified, i.e. the electrometer thereupon indicates a rise of a potential, which continually increases during a certain interval of time, some hours in the main, before reaching a limiting value. (The electrification was observed when the mud was removed from the cylinders.) The wire contained in the zinc cylinder becomes positively electrified, whilst that in the brass cylinder becomes negatively electrified. Having remarked such a phenomenon, we introduced into the brass cylinder which opened from beneath, a zinc cylinder, placed coaxially so as to enclose the wire. This cylinder was in metallic connection with the surrounding brass one. In this case, too, the wire acquired a potential, but it was opposite in sign to that it acquired without such a zinc cylinder being merely enclosed in the brass cylinder, i.e. it became positively electrified. The maximum value of the potential produced in the wire amounted in our observations to $0.2 \mathrm{~V}$. This maximum value depends, it seems, upon the degree of ionisation of the air in the cylinder.

We also replaced the zinc cylinder at the interior of the great brass cylinder by others of lead, aluminium, iron and silver, with the effect that the two former acted in the same direction as the zinc cylinder; the lead cylinder, which, by the bye, proved very radio-active, gave the strongest effect (about $0.35 \mathrm{~V}$ ), whilst aluminium took the last place, zinc remaining in the middle. The iron and the silver cylinders, on the contrary, exerted the same action as the main brass cylinder, giving a negative electrification, but to a less degree.

The phenomenon we have observed seems to be in correspondence with effects produced in metals by air ionised with Röntgen rays (I. Borgmann and A. Gerchun, $C$. R., cxxii. p. 378 , 1896; Minchin, the Electrician, March 27, I896; Rutherford, Phil. Mag., xliii. p. 241, I897). It may perhaps give the explanation of atmospheric electricity; and it is also of interest in the fact that here we take electrical energy directly from the air.

I. Borgmann.

Physical Institute, The University, St. Petersburg, May 9.

\section{Graphic Methods in an Educational Course on Mechanics.}

IT is difficult to reconcile Mr. Milne's opening statement (Nature, May 5, p. 5) with the rest of his letter. He begins by venturing to think that no one will gainsay $\mathrm{Mr}$. W. Larden's main contention (NATURE, April 28, p. 607) that " analytical methods give a grasp of the principles of statics while graphical methods disguise them," and he goes on to give half a dozen instances confuting it. $\mathrm{Mr}$. Larden wrote to elicit opinions from those who have taught mechanics, and as I have had only one pupil, a very troublesome one, namely, myself, I cannot think that my opinions are invited. But when Mr. Milne thinks that no one will gainsay the contention, the challenge is a wide one, and I deny it emphatically, and know that there are hundreds of men who will agree with me. These men are not teachers or mathematicians, but those who have to use mathematics for their profession or trade.

I have the highest admiration for all those to whom science is an end in itself. I fully appreciate the attitude of mind (the butt of so many jokes) which feels that mathematics and other sciences become degraded by useful applications. But for one true mathematician there are a thousand men to whom mathematics are but a means to an NO. I 804 , VOL. 70] end. Many of these, like myself, are not mathematically minded (as Mr. Larden probably counts mathematics), and with the exception of Maxwell's "reciprocal figures" and a few others, we have had to work out graphical methods mainly for ourselves. Teachers are now coming round, or as Mr. Larden would put it, giving way, or as I would put it, waking up, and are recognising that analytical language, powerful as it is for research, is not paramount for explanation. "I believe," wrote Prof. J. Perry in his "Spinning Tops," "that there are very few mathematical explanations of phenomena which may not be given in quite ordinary language to people who have an ordinary amount of experience. In most cases the symbolical algebraic expression must be given first by somebody, and then comes the time for its translation into ordinary language."

I agree with the whole of Mr. Milne's letter except the first few words, and, like him, "I believe the best results will be obtained when the two methods are used side by side." Of my own acquaintances, about one in five prefer analytical methods, but the others have a diagram in their heads, if not before them on paper as a guide to bring it vividly before the mind (to borrow. Mr. Larden's words). Mr. Larden concludes, " graphical work consumes an amount of time that seems out of proportion to the mental training and knowledge of principles gained." The title of his letter shows that he has " an educational course" in view, and qua education, "mental training and knowledge of principles" is the true and only object. His pupils should emerge as mathematicians. But those who have to use statics professionally would not hesitate to consume twice or thrice the time on a graphical method if it carries conviction of truth with it, as it does to two or three at least out of five of my acquaintances.

Mr. Larden dates his letter from Devonport, and this suggests that some of his pupils hope to become naval officers and not wranglers; that mathematics will be used by them in after life as a means to an end. Would he deny the use of a piece of string on a globe to explain "great circle sailing," or does he use a formula applicable generally to figures of revolution, of which the earth and Saturn's ring are particular cases? Sumner's method may be disguised in algebra, but it must be confessed that the famous "line" as discovered by him was a bit of pure graphics.

It may be impossible for Mr. Larden to appreciate the geometrical point of view, for my contentions are exactly the opposite of his first and fourth. For us non-mathematicians, "graphical methods give a grasp of the principles of statics, while analytical methods disguise them," and "analytical methods confuse learners of statics." The second contention, "Analytical methods must be mastered in any case," needs the addition of the words " by the help of diagrams." If there be any truth in the third contention, that " analytical methods connect statics with dynamics," it is of small importance if they fail to elucidate dynamics. Nature herself gainsays these contentions with the parabola of the fountain, the ripple of the pond, and the slope of the sand hill.

A. P. Trotter.

8 Richmond Terrace, Whitehall, S.W., May 13.

Any educational course in mechanics should undoubtedly be based first of all on experiment. If such is the case, it is practically impossible for any student using " graphical methods" to make the wild "shots" referred to by $\mathrm{Mr}$. Larden (vol. lxix. p. 607), who seems to have been very unfortunate in the kind of boy he has received from "a preparatory school "; or is it the boy who has been unfortunate in his previous training? Has Mr. Larden considered the possibility of the "method of teaching " adopted being wrong in the aforesaid school? Surely there is no inherent quality in " graphical methods" to cause these wildest of " shots." The writer's experience goes entirely against this idea, and supports the cortentions set forth by Mr. Milne.

Mr. Larden writes :- "If then, there be not time for both, it is the latter (Graphics) that should be sacrificed." If time is so short that some sacrifice must be made, the 